Article

\title{
Study of the Quality Attributes of Selected Blueberry (Vaccinium corymbosum L.) Varieties Grown under Different Irrigation Regimes and Cultivation Systems
}

\author{
José L. Ordóñez-Díaz ${ }^{1, *,+}$, , Gema Pereira-Caro ${ }^{1,+} \oplus$, Vanessa Cardeñosa ${ }^{1}$, José L. Muriel ${ }^{2}$ \\ and José M. Moreno-Rojas ${ }^{1, *(D)}$ \\ 1 Department of Food Science and Health, Andalusian Institute of Agricultural and Fisheries Research and \\ Training (IFAPA), Avenida Menendez-Pidal, SN, 14004 Córdoba, Spain; \\ mariag.pereira@juntadeandalucia.es (G.P.-C.); vanessa.cardeñosa@juntadeandalucia.es (V.C.) \\ 2 Department of Natural Resources and Organic Production, Andalusian Institute of Agricultural and \\ Fisheries Research and Training (IFAPA) Las Torres-Tomejil, Ctra. Sevilla-Cazalla Km. 12,2, Alcalá del Rio, \\ 41200 Seville, Spain; josel.muriel@juntadeandalucia.es \\ * Correspondence: josel.ordonez@juntadeandalucia.es (J.L.O.-D.); \\ josem.moreno.rojas@juntadeandalucia.es (J.M.M.-R.) \\ + These authors contributed equally to this work.
}

Received: 20 October 2020; Accepted: 24 November 2020; Published: 27 November 2020

\begin{abstract}
Quality parameters are always of major importance in fruit sensory perception and they are influenced by the agriculture and environmental strategies of water-use efficiency that in the last few years are being developed due to water scarcity. Blueberry fruit quality depends on several factors, such as variety, water availability or cultivation system. The purpose of this work was to determine the effect of deficit irrigation and cultivation systems on the quality of three blueberry cultivars along two consecutive seasons. Three blueberry varieties ('Rocio', V2 and V3) were subjected to two irrigation regimes (100\% and $80 \%$ crop evapotranspiration) and grown under two cultivation systems (open field and plastic tunnels). Their quality attributes (color, sugars, acidity, firmness, size and weight) were evaluated over two consecutive seasons (2011-2012). The application of deficit irrigation did not significantly affect the quality parameters, except for an increase in firmness. The cultivation system used influenced the quality attributes of blueberries cultivated under plastic tunnels in both seasons, increasing the soluble solids content and decreasing the titratable acidity. All the studied quality parameters were significantly affected by genetic factors. The V2 cultivar was the most influenced by the cultivation system. In conclusion, the use of deficit irrigation and plastic tunnels in blueberry cultivation is a good alternative to obtain fruits with enhanced quality features.
\end{abstract}

Keywords: deficit irrigation; plastic tunnels; blueberry; food quality; crop evapotranspiration; water stress; color

\section{Introduction}

The blueberry (Vaccinium corymbosum L.), belonging to the Ericaceae family, is a perennial evergreen or deciduous shrub native to North America and is one of the most important berry cultivars that have been established in Andalusia in the last decade ( $>3400,92.5 \%$ of total Spanish cultivation in 2018) with an annual production of 42,000 tons, reaching 97\% of blueberry production in Spain in 2018 [1].

A factor limiting the development of the crop is the wind, which causes fruit drop and produces scratches on the berries. The flowering season should be free of frost periods and slightly acidic soils are required. It is a plant of ecological interest, not only for its fruit but also because it protects the forest floor from erosion and contributes to the formation of humus. Moreover, blueberries are rich 
sources of antioxidant compounds [2,3] and their consumption is associated with the prevention of various human diseases related with oxidative stress, such as degenerative and cardiovascular diseases, chronic inflammation and cancer [4].

As occurs with other agricultural products, the quality of blueberries depends on several factors. Thus, the cultivar, climate, soil, water availability, cultural practices and degree of maturity are known to have a significant effect on the nutrient and metabolite concentrations in several crops [5-7]. Besides, fruit quality is influenced by the agronomic factors, such as cultivation systems, microbial inoculants, plant nutrition or soil management [7]. Thus, an acidic $\mathrm{pH}$ in the soil is essential to improve fruit development and quality [8].

Drought is an important environmental stress factor limiting agriculture worldwide [9]. Mean global temperatures are expected to rise over the next few decades, leading to increased evaporation rates, which will result in increased crop demand of water [10]. Water shortages are forcing growers to consider adopting water saving strategies [11]. Besides, a water-efficient irrigation could prevent nitrate leaching, which is one the major environmental issues in the Andalusian region [12]. Deficit irrigation strategies (less than 100\% crop needs of water) can also be used to reduce the demand for irrigation water [13-16]. Different berry varieties have been found to present variations in the concentration of some taste compounds in response to limited water availability [17-20].

In this regard, a considerable variation in quality attributes among varieties and species of various blueberry genotypes has been reported [21-23]. This provides an opportunity for selecting and breeding new varieties with improved nutritional quality. For decades breeding programs have predominantly focused on creating varieties with improved commercial traits, such as large berry size, light berry color, small scars, desirable flavor, improved firmness and high productivity [24].

Recently, research has been focused on improving the fruit quality and the nutritional value, especially to identify varieties rich in phenolic compounds $[25,26]$.

The biosynthesis of many phytochemicals in fruits and vegetables is the result of environmental interactions [27,28]. A growing number of studies have shown that agronomic practices (i.e., culture in greenhouses or fields, organic cultivation) also affect the concentration of some taste-related and bioactive molecules in fruits and vegetables [29-33].

Hence, the aim of this study was to evaluate the quality of three blueberry cultivars with different irrigation treatments and cultivation systems over two consecutive seasons.

\section{Materials and Methods}

\subsection{Samples}

Plants from three blueberry cultivars ('Rocio', and two experimental ones, V2 and V3) were grown under two cultivation systems (open field and plastic tunnels) and subjected to two irrigation regimes (100\% and $80 \%$ crop evapotranspiration).

The study was carried out in a commercial plot of approximately $11,000 \mathrm{~m}^{2}$ (latitude: $37^{\circ} 10.3^{\prime} 79^{\prime \prime} \mathrm{N}$; longitude: $6^{\circ} 29.20^{\prime} 43^{\prime \prime} \mathrm{W}$ ) belonging to a partner company located in the Doñana National Park (Almonte, Huelva, SW Spain). The experimental design was a strip-split-plot with four blocks in which the cultivars were randomly distributed ( 3 cultivars $\times 2$ cultivation systems $\times 2$ irrigation treatments $\times 4$ blocks $=48$ per season). The elementary plot $(56 \times 4.26 \mathrm{~m}$ with 150 each $)$ included two rows of plants installed on ridges $70 \mathrm{~cm}$ high and with a base of $1.6 \mathrm{~m}$. Drip irrigation lines were used with four emitters per plant line: two for water irrigation and two others for integrated drip fertigation. Blueberry plants were managed following a standard nutrient solution for blueberries. The main nutrients applied in fertigation were $\mathrm{N}\left(\mathrm{N}-\mathrm{NH}_{4}+\mathrm{N}-\mathrm{NO}_{3}\right)(70 \mathrm{~kg} / \mathrm{ha}), \mathrm{P}_{2} \mathrm{O}_{5}(30 \mathrm{~kg} / \mathrm{ha}), \mathrm{K}_{2} \mathrm{O}(80 \mathrm{~kg} / \mathrm{ha})$ and $\mathrm{MgO}(30 \mathrm{~kg} / \mathrm{ha})$. $\mathrm{pH}$ was maintained between 5-5.50 using phosphoric acid in the irrigation water. No fungicides and pesticides were necessary during the growing season. The irrigation lines were distributed in the same way, differing only in the drip rate: $2.6 \mathrm{~L} / \mathrm{h}$ for control treatment and $2.1 \mathrm{~L} / \mathrm{h}$ for the deficit irrigation treatment. The measurement of water applied at each treatment was performed 
with a Iberconta analog and pulse water meters (registered in datalogger and calibrated to circulate $10 \mathrm{~L}$ per pulse). The moisture in the soil was measured by installing capacitance probes in the frequency (FDR, frequency domain reflectometry) or time (TDR, time domain reflectometry) domains.

The berries were collected in the same maturity stage in two consecutive seasons (2011 and 2012). The commercial maturity was defined as homogeneous blue color and a minimum value for SST of $11^{\circ}$ Brix. Thus, samples were collected 6 times during the harvesting period, from April to June. The sampling was performed with four replicates per variety, treatment and cultivation system. Each replicate consisted of $500 \mathrm{~g}$ of berries from ten different bushes of three years of age and measuring over a meter in height. After their collection, the samples were transported from the field to the laboratory under refrigerated conditions and stored in the dark at $4{ }^{\circ} \mathrm{C}$ until their analysis (day after harvesting). The blueberries were evaluated for their quality attributes: soluble solids content, titratable acidity, firmness, color, weight and size (diameter). The factors evaluated were variety (V), sampling year (SY), cultivation system (CS) and irrigation regime (IR).

\subsection{Weight and Diameter Assessment}

Twenty randomly selected fruits from each treatment and replication were used to evaluate the weight and the diameter. The weight was evaluated with a balance and diameter with a digital caliper. The average diameter and weight per berry were calculated.

\subsection{Color}

The CIELab color (color space defined by the International Commission on Illumination in 1976) was evaluated using a Minolta CR-400 colorimeter. Ten fruits were sampled from each treatment, and two readings were taken on opposite sides of each fruit. All the readings were performed externally in the middle of the fruit. The instrument was calibrated with a ceramic white calibration standard $(\mathrm{Y}=94.3, \mathrm{x}=0.3159, \mathrm{y}=0.3325)$. The $\mathrm{L}^{*}$ (lightness), $\mathrm{a}^{*}$ (greenness [-] to redness [+]) and $\mathrm{b}^{*}$ (blueness [-] to yellowness $[+])$ color parameters were measured, and the corresponding values of hue angle $(\mathrm{h})$ and chroma $\left(\mathrm{C}^{*}\right)$ were calculated.

\subsection{Firmness}

Firmness was determined using a TA-XT-Plus texture analyzer equipped with a $2 \mathrm{~mm}$ diameter flat probe. Ten fruits from each treatment were deformed $5 \mathrm{~mm}$ at a rate of $40 \mathrm{~mm} / \mathrm{s}$ and the maximum force developed during the test was recorded. The results are expressed in newtons $(\mathrm{N})$.

\subsection{Titratable Acidity (TA) and $p H$}

The $\mathrm{pH}$ was measured potentiometrically and the acidity was determined titrimetrically with $0.1 \mathrm{M} \mathrm{NaOH}$ until $\mathrm{pH} 8.1$ by an automatic Mettler Toledo T70 titrosampler. The results are expressed as grams of citric acid per $100 \mathrm{~g}$ of fresh weight.

\subsection{Soluble Solids Content (SSC)}

SSC was determined by a digital refractometer (Atago RX-1000) and expressed as brix degrees.

\subsection{Statistical Analysis}

Statistical analyses were carried out using Statistix 9.0 software. All the data were subjected to variance analyses (ANOVA) with a strip-split-plot design. The means were compared with a LSD (Fisher's Least Significant Difference) test at a significance level of $95 \%(p=0.05)$. Values were considered statistically significant at $p$-value $\leq 0.05$. 


\section{Results and Discussion}

\subsection{Influence of Deficit Irrigation on Fruit Quality}

Blueberry plants are generally irrigated and are very rarely subjected to conditions of water stress [34]. However, in areas where water resources are already scarce or threatened, such as the Doñana National Park (Southwest Spain), where this research was performed, water deficit irrigation (DI) technique has been proposed as a potential alternative. Based on our results, the quality of the blueberry fruits under a deficit irrigation regime did not appear to be impaired (Table 1). The only significant difference obtained after statistical treatment was related to fruit firmness. In our case, the blueberries collected under the deficit irrigation regime $(80 \% \mathrm{ETc})$ presented an increase in the firmness values, a parameter impacting positively on the post-harvest life of the fruits (transportation, conservation and shelf-life). These results are in accordance with other studies reporting similar results in strawberry fruits [35].

Table 1. Effect of variety, sampling year, cultivation system and irrigation regime on quality parameters of blueberries.

\begin{tabular}{|c|c|c|c|c|c|c|c|c|c|}
\hline & SSC & TA & $\mathrm{pH}$ & Firmness & $\mathbf{h}^{\circ}$ & $C^{*}$ & $\mathbf{L}^{*}$ & Weight & Size \\
\hline \multicolumn{10}{|l|}{ Variety } \\
\hline 'Rocio' & $14.77^{\mathrm{a}}$ & $0.52^{\mathrm{a}}$ & $3.62^{c}$ & $1.62^{\mathrm{c}}$ & $279.6^{\mathrm{a}}$ & $4.55^{c}$ & $30.75^{c}$ & $2.09^{b}$ & $15.05^{c}$ \\
\hline $\mathrm{V} 2$ & $13.65^{b}$ & $0.42^{b}$ & $3.77^{b}$ & $1.97^{\mathrm{a}}$ & $268.4^{c}$ & $5.71^{a}$ & $35.40^{\mathrm{a}}$ & $2.27^{b}$ & $15.84^{b}$ \\
\hline V3 & $12.89^{c}$ & $0.35^{\mathrm{c}}$ & $3.99^{\mathrm{a}}$ & $1.84^{\mathrm{b}}$ & $271.8^{b}$ & $4.98^{\mathrm{b}}$ & $31.63^{b}$ & $2.79^{a}$ & $16.94^{\mathrm{a}}$ \\
\hline \multicolumn{10}{|l|}{ Sampling year } \\
\hline 2011 & 13.66 & $0.32^{b}$ & $4.14^{\mathrm{a}}$ & $1.65^{b}$ & $270.5^{b}$ & $4.68^{b}$ & $32.33^{b}$ & 2.46 & $15.59^{b}$ \\
\hline 2012 & 13.88 & $0.53^{a}$ & $3.44^{\mathrm{b}}$ & $1.96^{\mathrm{a}}$ & $276.1^{\mathrm{a}}$ & $5.47^{\mathrm{a}}$ & $32.95^{\mathrm{a}}$ & 2.31 & $16.29^{a}$ \\
\hline \multicolumn{10}{|l|}{ Cultivation system } \\
\hline Open field & $12.86^{b}$ & $0.52^{\mathrm{a}}$ & $3.62^{b}$ & 1.81 & 273.3 & 5.19 & 32.57 & 2.32 & 15.90 \\
\hline Plastic tunnels & $14.68^{\mathrm{a}}$ & $0.34^{b}$ & $3.97^{\mathrm{a}}$ & 1.81 & 273.3 & 4.96 & 32.61 & 2.45 & 15.98 \\
\hline \multicolumn{10}{|l|}{ Irrigation regime } \\
\hline $100 \% \mathrm{ET}_{\mathrm{c}}$ & 13.73 & 0.43 & 3.76 & $1.77^{\mathrm{b}}$ & 272.9 & 5.14 & 32.60 & 2.40 & 15.95 \\
\hline $80 \% \mathrm{ET}_{\mathrm{c}}$ & 13.81 & 0.42 & 3.82 & $1.85^{\mathrm{a}}$ & 273.6 & 5.02 & 32.50 & 2.37 & 15.93 \\
\hline Variety (V) & $* * *$ & $* * *$ & $* * *$ & $* * *$ & $* * *$ & $* * *$ & $* * *$ & $* * *$ & $* * *$ \\
\hline Sampling year (SY) & ns & $* * *$ & $* * *$ & $* * *$ & $* * *$ & $* * *$ & * & ns & $* * *$ \\
\hline Cultivation system (CS) & $* *$ & $* * *$ & $* * *$ & ns & ns & ns & ns & ns & ns \\
\hline Irrigation regime (IR) & ns & ns & ns & $* *$ & ns & ns & ns & ns & ns \\
\hline $\mathrm{V} \times \mathrm{SY}$ & $* * *$ & $* *$ & $* * *$ & ns & $* *$ & $*$ & ns & $* * *$ & $* * *$ \\
\hline $\mathrm{V} \times \mathrm{CS}$ & $* *$ & $*$ & $*$ & ns & ns & $* *$ & $*$ & ns & ns \\
\hline $\mathbf{V} \times \mathbf{I R}$ & ns & ns & ns & ns & ns & ns & ns & ns & ns \\
\hline$S Y \times C S$ & $*$ & ns & $* * *$ & ns & ns & ns & ns & ns & $*$ \\
\hline$S Y \times I R$ & ns & ns & ns & ns & ns & ns & ns & ns & ns \\
\hline $\mathrm{CS} \times \mathrm{IR}$ & ns & ns & ns & ns & ns & ns & ns & ns & ns \\
\hline
\end{tabular}

Different letters indicate significant differences by LSD (Fisher's Least Significant Difference) test. * ${ }^{* *}, * * *$, ns-significant at $p<0.05, p<0.01, p<0.001$ and not significant, respectively. SSC: soluble solids content ( ${ }^{\circ}$ Brix); TA: titratable acidity (\% citric acid); Firmness $(\mathrm{N})$; $\mathrm{L}^{*}$ : lightness; $\mathrm{h}^{\circ}$ : hue angle; $\mathrm{C}^{*}$ : chroma; weight $(\mathrm{g})$; size $(\mathrm{mm})$.

In our study, berry weight and size were unaffected by irrigation and this fact was consistent in both sampling years and in all the studied cultivars (Table 1). In the literature, we can find controversial results regarding those parameters. Some authors showed that deficit irrigation has been associated with a reduction in berry size and weight in blueberry [36], and some others observed that an increase in the water supply reduced the fruit firmness and increased fruit size [37]. In this sense, other studies suggested that changes in firmness resulting from increases in irrigation were not always associated with changes in fruit size [20,38].

In general, the three cultivars analyzed in this study showed a low susceptibility to the deficit irrigation applied. 


\subsection{Influence of the Cultivation System on Fruit Quality}

Fruits grown under cover are known to reach physiological maturity earlier $[39,40]$. Thus, Ogden and Van Iersel [41] found that high tunnels affected microclimatic conditions, which induced changes in the flowering and vegetative development of blueberry plants.

The taste of blueberries might be expected to be significantly affected by cultivation practices due to the relationship among sugars, acidity and ripening. The fruits grown under plastic tunnels showed the lowest acidity and the highest $\mathrm{pH}$ and SSC values (Table 1). Sugars and organic acids have an important impact on the sensory quality of fruit, so a balanced ratio of SSC and TA are desirable characteristics that improve its taste. In this context, it must be considered that the general flavor selection criteria for fruit are a combination of high sweetness and moderate acidity [42].

The remaining parameters studied were not significantly affected by the cultivation system. The maximum daily temperature was consistently $2-5{ }^{\circ} \mathrm{C}$ higher in the tunnels compared with the outdoor control plants in both sampling years (Figure 1). This trend was previously observed by Kadir et al. [43] and Ogden and Van Iersel [41]. Likewise, there was less sunlight under the plastic tunnels than outdoors (Figure 1). The lower radiation and the higher temperature recorded under the plastic tunnels could be responsible for the increase in SSC in the berries grown under this type of cultivation system. Thus, other researchers have found that strawberry fruits produced inside high tunnels had a higher concentration of soluble solids than those grown outside [43]. However, other studies have observed that the soluble solids content of blueberries grown under shades remained unchanged [44] or decreased [45].

\section{1}
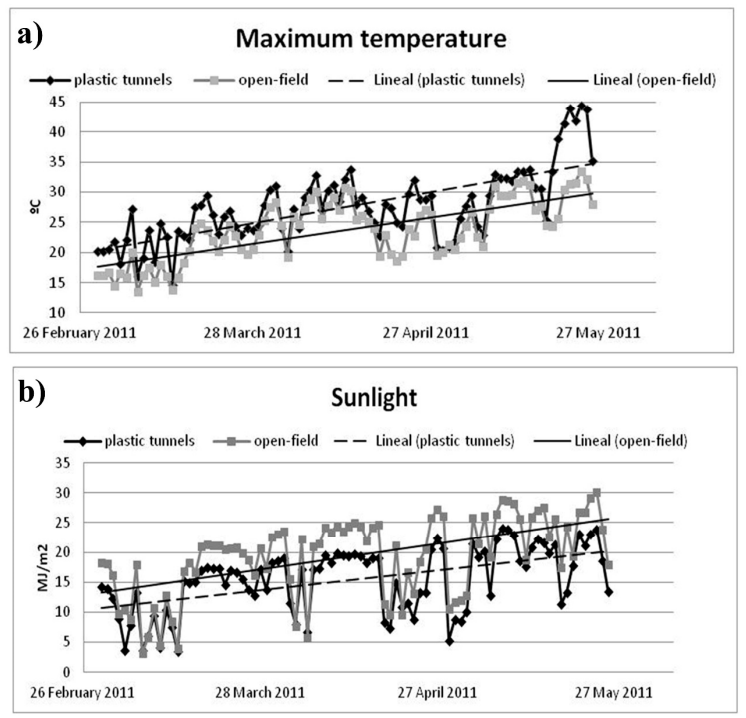

2012
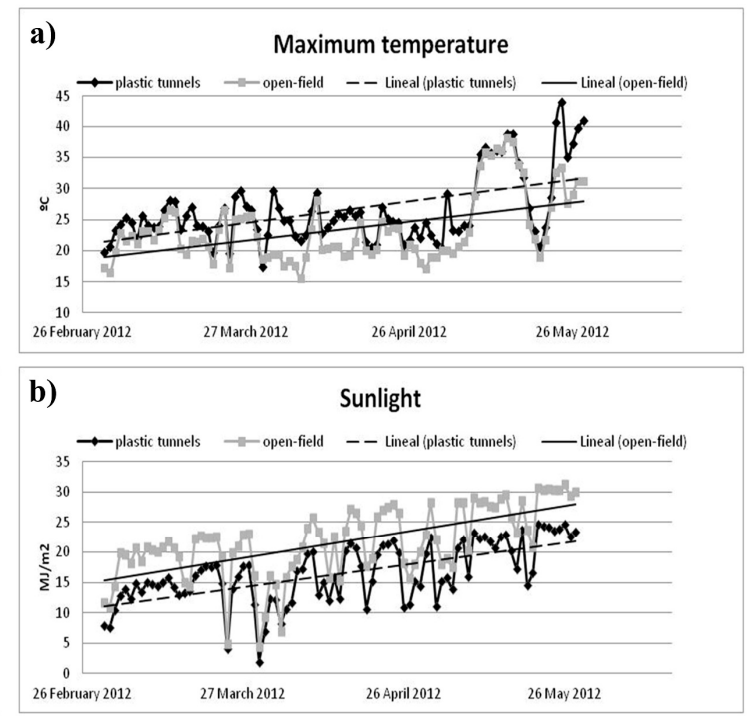

Figure 1. Maximum temperature (a) and sunlight (b) recorded in plastic tunnels and open field in 2011 (left) and 2012 (right) years.

\subsubsection{Interactions $\mathrm{CS} \times \mathrm{SY}$}

The main interaction observed between the cultivation system (CS) and sampling year (SY) of note (Table 2) was related to the average berry size. In 2012 berries grown under plastic tunnels were not significantly different from those cultivated under the open field conditions. On the other hand, in 2011, we found significant differences for this factor between the samples harvested from open field (smaller) and those from plastic tunnels. 
Table 2. Effect of cultivation system and sampling year on the parameters evaluated for blueberry fruits.

\begin{tabular}{ccccccccccc}
\hline & & SSC & TA & pH & Firmness & $\mathbf{h}^{\circ}$ & $\mathbf{C}^{*}$ & $\mathbf{L}^{*}$ & Weight & Size \\
\hline \multirow{2}{*}{ Open field } & 2011 & $12.42^{\mathrm{c}}$ & 0.42 & $3.92^{\mathrm{b}}$ & 1.66 & 269.98 & 4.69 & 32.32 & 2.32 & $15.39^{\mathrm{c}}$ \\
& 2012 & $13.31^{\mathrm{b}}$ & 0.62 & $3.32^{\mathrm{d}}$ & 1.95 & 276.51 & 5.69 & 32.82 & 2.32 & $16.42^{\mathrm{a}}$ \\
\hline \multirow{2}{*}{ Plastic Tunnels } & 2011 & $14.89^{\mathrm{a}}$ & 0.22 & $4.37^{\mathrm{a}}$ & 1.64 & 270.96 & 4.67 & 32.14 & 2.59 & $15.80^{\mathrm{b}}$ \\
& 2012 & $14.46^{\mathrm{a}}$ & 0.45 & $3.56^{\mathrm{c}}$ & 1.97 & 275.59 & 5.26 & 33.08 & 2.31 & $16.17^{\mathrm{a}}$ \\
\hline
\end{tabular}

Different letters within a column indicate significant differences by LSD test. SSC: soluble solids content $\left({ }^{\circ}\right.$ Brix);

TA: titratable acidity (\% citric acid); Firmness (N); $\mathrm{L}^{*}$ : lightness; $\mathrm{h}^{\circ}$ : hue angle; $\mathrm{C}^{*}$ : chroma; weight $(\mathrm{g})$; size $(\mathrm{mm})$.

\subsubsection{Interactions $\mathrm{CS} \times \mathrm{V}$}

We observed significant interactions between the variety (V) and cultivation system for SSC, acidity and color. As mentioned before, plastic tunnels led to an increase in SSC and a decrease in the acidity of the blueberry fruits, which strongly varied depending on the genotypes. This fact was closely related to the effect of irradiation and light and had a direct impact on the amount of organic acids in the fruit as other authors suggested [46-48]. In this sense, we observed that the V2 cultivar was the most influenced by the cultivation system (18\% increase in SSC and $46 \%$ decrease in acidity) (Table 3$)$.

Table 3. Effects of cultivation system and genotype on the parameters evaluated for blueberry fruits.

\begin{tabular}{|c|c|c|c|c|c|c|c|c|c|c|}
\hline & & SSC & TA & $\mathrm{pH}$ & Firmness & $\mathbf{h}^{\circ}$ & $C^{*}$ & $\mathbf{L}^{*}$ & Weight & Size \\
\hline \multirow[b]{2}{*}{ Open Field } & 'Rocío' & $13.54^{c}$ & $0.61^{\mathrm{a}}$ & $3.46^{\mathrm{d}}$ & 1.64 & 279.82 & $4.57^{c}$ & $30.54^{\mathrm{d}}$ & 2.02 & 15.06 \\
\hline & $\mathrm{V} 2$ & $12.54^{\mathrm{d}, \mathrm{e}}$ & $0.54^{b}$ & $3.54^{\mathrm{d}}$ & 1.91 & 268.46 & $5.74^{\mathrm{a}}$ & $35.19^{a}$ & 2.19 & 15.69 \\
\hline \multirow{3}{*}{ Plastic Tunnels } & 'Rocío' & $15.99^{a}$ & $0.43^{c}$ & $3.77^{\mathrm{c}}$ & 1.59 & 279.28 & $4.53^{c}$ & $30.96^{c, d}$ & 2.17 & 15.03 \\
\hline & $\mathrm{V} 2$ & $14.76^{\mathrm{b}}$ & $0.29^{d}$ & $4.01^{b}$ & 2.03 & 268.33 & $5.67^{a, b}$ & $35.60^{\mathrm{a}}$ & 2.36 & 16.00 \\
\hline & V3 & $13.27^{\mathrm{c}, \mathrm{d}}$ & $0.29^{d}$ & $4.13^{\mathrm{a}}$ & 1.81 & 272.22 & $4.70^{c}$ & $31.28^{b, c}$ & 2.82 & 16.93 \\
\hline
\end{tabular}

Different letters within a column indicate significant differences by LSD test. SSC: soluble solids content ( ${ }^{\circ}$ Brix);

TA: titratable acidity (\% citric acid); firmness (N); $\mathrm{L}^{*}$ : lightness; $\mathrm{h}^{\circ}$ : hue angle; $\mathrm{C}^{*}$ : chroma; weight $(\mathrm{g})$; size (mm).

\subsection{Influence of Genotype on Fruit Quality}

All the studied parameters were strongly influenced by the cultivar (Table 1), which is consistent with data reported by other authors [22,49].

'Rocio' was the cultivar with the highest SSC and TA. Although, sugars are known to play an important role in the sensory quality of fruit, berry fruits with lower TA values were perceived as tasteless. Thus, a balanced SSC/TA ratio improves the overall sensory quality of blueberries. Besides, this cultivar showed the lowest average values in the quality parameters evaluated, such as firmness, fruit size and weight. Regarding color parameters, blueberries from the 'Rocio' variety were more bluish and had a darker and duller blue.

The V2 berries had the highest firmness values, whilst the values of SSC, TA and berry size were intermediate in comparison with the other two varieties. Regarding berry weight, they had the lowest values together with the 'Rocio' cultivar. Additionally, the berries from the V2 variety showed the lowest hue angle values and the highest values for chroma and lightness and therefore a bright and vivid blue fruit.

The berries from the V3 variety had the lowest values for acidity and SSC. These data could be linked to tasteless feeling. Moreover, the fruits from this cultivar showed the highest size and weight per berry. Consumer preferences regarding berry size are not clear and depend on the traditions of each region and how they are to be consumed (fresh consumption, decoration in desserts, etc.) [50]. Besides, the V3 berries presented intermediate values for firmness and color. 
Interactions $\mathrm{V} \times \mathrm{SY}$

Regarding the interaction between genotype and sampling year, the studied parameters were influenced in a different manner depending on the cultivar and the sampling year, except for firmness and lightness (Tables 1 and 4).

Table 4. Effect of genotype and sampling year on the parameters evaluated for blueberry fruits.

\begin{tabular}{|c|c|c|c|c|c|c|c|c|c|c|}
\hline & & SSC & TA & $\mathrm{pH}$ & Firmness & $h^{\circ}$ & $C^{*}$ & $\mathbf{L}^{*}$ & Weight & Size \\
\hline \multirow{2}{*}{ 'Rocio' } & 2011 & $13.69^{b, c}$ & $0.44^{b}$ & $3.84^{\mathrm{c}}$ & 1.52 & $276.1^{b}$ & $4.03^{\mathrm{d}}$ & 30.22 & $1.92 \mathrm{e}$ & $14.10^{\mathrm{c}}$ \\
\hline & 2012 & $15.84^{\mathrm{a}}$ & $0.59^{a}$ & $3.39^{d}$ & 1.71 & $283.0^{a}$ & $5.07^{b, c}$ & 31.28 & $2.28^{c, d}$ & $16.00^{b}$ \\
\hline \multirow{2}{*}{ V2 } & 2011 & $14.11^{b}$ & $0.33^{c}$ & $4.06^{b}$ & 1.77 & $267.0^{c}$ & $5.50^{\mathrm{a}, \mathrm{b}}$ & 34.98 & $2.43^{b, c}$ & $15.74^{b}$ \\
\hline & 2012 & $13.2^{\mathrm{c}, \mathrm{d}}$ & $0.50^{b}$ & $3.49^{\mathrm{d}}$ & 2.17 & $269.8^{c}$ & $5.92^{\mathrm{a}}$ & 35.81 & $2.12^{\mathrm{d}, \mathrm{e}}$ & $15.94^{b}$ \\
\hline \multirow{2}{*}{ V3 } & 2011 & $13.17^{c, d}$ & $0.19^{d}$ & $4.53^{\mathrm{a}}$ & 1.66 & $268.3^{c}$ & $4.53^{c}$ & 31.50 & $3.03^{a}$ & $16.94 \mathrm{a}$ \\
\hline & 2012 & $12.61^{\mathrm{d}}$ & $0.50^{b}$ & $3.45^{\mathrm{d}}$ & 2.01 & $275.4^{b}$ & $5.44^{a, b}$ & 31.77 & $2.55^{b}$ & $16.94^{a}$ \\
\hline
\end{tabular}

Different letters within a column indicate significant differences by LSD test. SSC: soluble solids content ( $\left.{ }^{\circ} \mathrm{Brix}\right)$;

TA: titratable acidity (\% citric acid); firmness (N); $L^{*}$ : lightness; $h^{\circ}$ : hue angle; $\mathrm{C}^{*}$ : chroma; weight $(\mathrm{g})$; size (mm).

These cultivars showed an increase in acidity in 2012. Thereby, V3 was the most affected with an increase of $62 \%$, while V2 and 'Rocio' increasing by $34 \%$ and $26 \%$, respectively. As regards SCC, different trends were observed between varieties and sampling years. Thus, the 'Rocio' cultivar showed an increase of $14 \%$ in SSC in 2012, while V2 had a significant decrease and no significant differences were found for this parameter for V3 between years (Table 4).

With regard to color parameters, the berries from the 'Rocio' and V3 cultivars showed higher $\mathrm{h}$ and $\mathrm{C}^{*}$ values (bluer berries with a more vivid blue) in 2012, while the V2 berries showed a similar color (h, $\mathrm{C}^{*}$ and $\mathrm{L}^{*}$ values) in both sampling years (Table 4$)$.

The average size and weight of the berries for each year depended on the cultivar. The 'Rocio' berries were bigger and heavier in 2012 than in 2011. The experimental cultivars V2 and V3 produced heavier berries in 2011 than in 2012 and of a similar size in both sampling years.

Previous studies with blueberries also found significant interactions between year and cultivar in several parameters evaluated, such as SSC and acidity [22] and fruit weight [49], which is in agreement with our data.

\section{Conclusions}

The use of deficit irrigation did not adversely affect the quality of the fruit from all the studied cultivars in this work; it even resulted in improved firmness.

The system of cultivation had an impact on several parameters defining fruit quality. The blueberries grown under plastic tunnels showed a decrease in acidity and an increase in soluble solids content compared to those grown in open fields.

A significant effect of genotype was observed on most of the studied parameters. The berries from the experimental cultivars (V2 and V3) were less sour, harder and bigger than those from the 'Rocio' cultivar.

The results lead to the conclusion that the use of deficit irrigation and plastic tunnels in blueberry cultivation is a good option for obtaining fruits with comparable or better quality characteristics.

Author Contributions: Conceptualization, J.L.M. and J.M.M.-R.; methodology, V.C. and J.M.M.-R.; validation, J.L.O.-D., G.P.-C. and J.M.M.-R.; formal analysis, J.L.O.-D., V.C. and J.M.M.-R.; investigation J.L.O.-D., G.P.-C., V.C., J.L.M. and J.M.M.-R.; resources, J.L.O.-D., G.P.-C., V.C., J.L.M. and J.M.M.-R.; data curation, J.L.O.-D., V.C. and J.M.M.-R.; writing—original draft preparation, J.L.O.-D., G.P.-C., V.C. and J.M.M.-R.; writing—review and editing, J.L.O.-D., G.P.-C., V.C., J.L.M. and J.M.M.-R.; supervision, J.L.M. and J.M.M.-R.; project administration, J.L.M. and J.M.M.-R. All authors have read and agreed to the published version of the manuscript.

Funding: This research received no external funding. 
Acknowledgments: J.L.O.-D. was granted a research contract funded by the Andalusian Institute of Agricultural and Fisheries Research and Training (IFAPA), inside the National Youth Guarantee System through the European Social Fund (ESF) and the Youth Employment Initiative (YEI). G.P.C. was granted a research contract funded by IFAPA and the ESF (03/2014 to 03/2017) and a postdoctoral research contract "Juan de la Cierva-Incorporación" funded by the Spanish Ministry of Economy and Competitiveness (FJCI-2015-26433). V.C. is grateful to IFAPA for the fellowship obtained for the development of her Ph.D. thesis. The authors would like to thank Juan Domínguez for his help in the statistical analysis.

Conflicts of Interest: The authors declare no conflict of interest.

\section{References}

1. The Ministry of Agriculture, Fisheries and Food. Available online: https://www.mapa.gob.es/en/ (accessed on 30 September 2020).

2. Gavrilova, V.; Kajdžanoska, M.; Gjamovski, V.; Stefova, M. Separation, characterization and quantification of phenolic compounds in blueberries and red and black currants by HPLC-DAD-ESI-MSn. J. Agric. Food Chem. 2011, 59, 4009-4018. [CrossRef]

3. Li, C.; Feng, J.; Huang, W.Y.; An, X.T. Composition of polyphenols and antioxidant activity of rabbiteye blueberry (Vaccinium ashei) in Nanjing. J. Agric. Food Chem. 2013, 61, 523-531. [CrossRef]

4. Tsao, R. Chemistry and biochemistry of dietary polyphenols. Nutrients 2010, 2, 1231-1246. [CrossRef]

5. Tulipani, S.; Marzban, G.; Herndl, A.; Laimer, M.; Mezzetti, B.; Battino, M. Influence of environmental and genetic factors on health-related compounds in strawberry. Food Chem. 2011, 124, 906-913. [CrossRef]

6. Ferrer-Gallego, R.; Hernández-Hierro, J.M.; Rivas-Gonzalo, J.C.; Escribano-Bailón, M.T. Influence of climatic conditions on the phenolic composition of Vitis vinifera L. cv. Graciano. Anal. Chim. Acta 2012, 732, 73-77. [CrossRef]

7. Di Vittori, L.; Mazzoni, L.; Battino, M.; Mezzetti, B. Pre-harvest factors influencing the quality of berries. Sci. Hortic. 2018, 233, 310-322. [CrossRef]

8. Albert, T.; Karp, K.; Starast, M.; Moor, U.; Paal, T. Effect of fertilization on the lowbush blueberry productivity and fruit composition in peat soil. J. Plant Nutr. 2011, 34, 1489-1496. [CrossRef]

9. Cattivelli, L.; Rizza, F.; Badeck, F.W.; Mazzucotelli, E.; Mastrangelo, A.M.; Francia, E.; Marè, C.; Tondelli, A.; Stanca, A.M. Drought tolerance improvement in crop plants: An integrated view from breeding to genomics. Field Crops Res. 2008, 105, 1-14. [CrossRef]

10. Haines, A. Climate Change 2001: The Scientific Basis. Contribution of Working Group 1 to the Third Assessment Report of the Intergovernmental Panel on Climate Change; Houghton, J.T., Ding, Y., Griggs, D.J., Noguer, M., van der Winden, P.J., Dai, X., Eds.; Cambridge University Press: Cambridge, UK, 2001; pp. 1-881.

11. Costa, J.M.; Ortuño, M.F.; Chaves, M.M. Deficit irrigation as a strategy to save water: Physiology and potential application to horticulture. J. Integr. Plant Biol. 2007, 49, 1421-1434. [CrossRef]

12. Tortosa, G.; Correa, D.; Sánchez-Raya, A.J.; Delgado, A.; Sánchez-Monedero, M.A.; Bedmar, E.J. Effects of nitrate contamination and seasonal variation on the denitrification and greenhouse gas production in La Rocina Stream (Doñana National Park, SW Spain). Ecol. Eng. 2011, 37, 539-548. [CrossRef]

13. Dos Santos, T.P.; Lopes, C.M.; Rodrigues, M.L.; De Souza, C.R.; Maroco, J.P.; Pereira, J.S.; Silva, J.R.; Chaves, M.M. Partial rootzone drying: Effects on growth and fruit quality of field-grown grapevines (Vitis vinifera). Funct. Plant Biol. 2003, 30, 663-671. [CrossRef]

14. Grant, O.M.; Stoll, M.; Jones, H.G. Partial rootzone drying does not affect fruit yield of raspberries. J. Hortic. Sci. Biotechnol. 2004, 79, 125-130. [CrossRef]

15. Lobos, T.E.; Retamales, J.B.; Ortega-Farías, S.; Hanson, E.J.; López-Olivari, R.; Mora, M.L. Pre-harvest regulated deficit irrigation management effects on post-harvest quality and condition of $V$. corymbosum fruits cv. Brigitta. Sci. Hortic. 2016, 207, 152-159. [CrossRef]

16. Lobos, T.E.; Retamales, J.B.; Ortega-Farías, S.; Hanson, E.J.; López-Olivari, R.; Mora, M.L. Regulated deficit irrigation effects on physiological parameters, yield, fruit quality and antioxidants of Vaccinium corymbosum plants cv. Brigitta. Irrig. Sci. 2018, 36, 49-60. [CrossRef]

17. Castellarin, S.D.; Matthews, M.A.; Di Gaspero, G.; Gambetta, G.A. Water deficits accelerate ripening and induce changes in gene expression regulating flavonoid biosynthesis in grape berries. Planta 2007, 227, 101-112. [CrossRef] 
18. Giné Bordonaba, J.; Terry, L.A. Manipulating the taste-related composition of strawberry fruits (Fragaria $\times$ ananassa) from different cultivars using deficit irrigation. Food Chem. 2010, 122, 1020-1026. [CrossRef]

19. Grant, O.M.; Johnson, A.W.; Davies, M.J.; James, C.M.; Simpson, D.W. Physiological and morphological diversity of cultivated strawberry (Fragaria $\times$ ananassa) in response to water deficit. Environ. Exp. Bot. 2010, 68, 264-272. [CrossRef]

20. Ehret, D.L.; Frey, B.; Forge, T.; Helmer, T.; Bryla, D.R. Effects of drip irrigation configuration and rate on yield and fruit quality of young Highbush blueberry plants. HortScience 2012, 47, 414-421. [CrossRef]

21. Kalt, W.; Ryan, D.A.J.; Duy, J.C.; Prior, R.L.; Ehlenfeldt, M.K.; Vander Kloet, S.P. Interspecific variation in anthocyanins, phenolics, and antioxidant capacity among genotypes of highbush and lowbush blueberries (Vaccinium section cyanococcus spp.). J. Agric. Food Chem. 2001, 49, 4761-4767. [CrossRef]

22. Wang, S.Y.; Chen, H.; Camp, M.J.; Ehlenfeldt, M.K. Genotype and growing season influence blueberry antioxidant capacity and other quality attributes. Int. J. Food Sci. Tech. 2012, 47, 1540-1549. [CrossRef]

23. Montecchiarini, M.L.; Bello, F.; Rivadeneira, M.F.; Vázquez, D.; Podestá, F.E.; Tripodi, K.E.J. Metabolic and physiologic profile during the fruit ripening of three blueberries highbush (Vaccinium corymbosum) cultivars. J. Berry Res. 2018, 8, 177-192. [CrossRef]

24. Scalzo, J.; Stevenson, D.; Hedderley, D. Polyphenol compounds and other quality traits in blueberry cultivars. J. Berry Res. 2015, 5, 117-130. [CrossRef]

25. Scalzo, J.; Politi, A.; Pellegrini, N.; Mezzetti, B.; Battino, M. Plant genotype affects total antioxidant capacity and phenolic contents in fruit. Nutrition 2005, 21, 207-213. [CrossRef]

26. Corona, G.; Tang, F.; Vauzour, D.; Rodriguez-Mateos, A.; Spencer, J.P.E. Assessment of the anthocyanidin content of common fruits and development of a test diet rich in a range of anthocyanins. J. Berry Res. 2011, 1, 209-216. [CrossRef]

27. Connor, A.M.; Luby, J.J.; Tong, C.B.S.; Finn, C.E.; Hancock, J.F. Genotypic and environmental variation in antioxidant activity, total phenolic content, and anthocyanin content among blueberry cultivars. J. Am. Soc. Hortic. Sci. 2002, 127, 89-97. [CrossRef]

28. Wang, S.Y.; Chen, C.T.; Wang, C.Y. The influence of light and maturity on fruit quality and flavonoid content of red raspberries. Food Chem. 2009, 112, 676-684. [CrossRef]

29. Bourn, D.; Prescott, J. A comparison of the nutritional value, sensory qualities, and food safety of organically and conventionally produced foods. Crit. Rev. Food Sci. Nutr. 2002, 42, 1-34. [CrossRef]

30. Asami, D.K.; Hong, Y.J.; Barrett, D.M.; Mitchell, A.E. Comparison of the total phenolic and ascorbic acid content of freeze-dried and air-dried marionberry, strawberry, and corn grown using conventional, organic, and sustainable agricultural practices. J. Agric. Food Chem. 2003, 51, 1237-1241. [CrossRef]

31. Crecente-Campo, J.; Nunes-Damaceno, M.; Romero-Rodríguez, M.A.; Vázquez-Odériz, M.L. Color, anthocyanin pigment, ascorbic acid and total phenolic compound determination in organic versus conventional strawberries (Fragariaxananassa Duch, cv Selva). J. Food Compos. Anal. 2012, 28, 23-30. [CrossRef]

32. Cardeñosa, V.; Medrano, E.; Lorenzo, P.; Sánchez-Guerrero, M.C.; Cuevas, F.; Pradas, I.; Moreno-Rojas, J.M. Effects of salinity and nitrogen supply on the quality and health-related compounds of strawberry fruits (Fragaria $\times$ ananassa cv. Primoris). J. Sci. Food Agric. 2015, 95, 2924-2930. [CrossRef]

33. Cardeñosa, V.; Girones-Vilaplana, A.; Muriel, J.L.; Moreno, D.A.; Moreno-Rojas, J.M. Influence of genotype, cultivation system and irrigation regime on antioxidant capacity and selected phenolics of blueberries (Vaccinium corymbosum L.). Food Chem. 2016, 202, 276-283. [CrossRef] [PubMed]

34. Mingeau, M.; Perrier, C.; Améglio, T. Evidence of drought-sensitive periods from flowering to maturity on highbush blueberry. Sci. Hortic. 2001, 89, 23-40. [CrossRef]

35. Prange, R.K.; DeEll, J.R. Preharvest factors affecting postharvest quality of berry crops. HortScience 1997, 32, 824-830. [CrossRef]

36. Bryla, D.R.; Yorgey, B.; Shireman, A.D. Irrigation management effects on yield and fruit quality of highbush blueberry. Acta Hortic. 2009, 810, 649-656. [CrossRef]

37. Bryla, D.R. Water requirements of young blueberry plants irrigated by sprinklers, microsprays and drip. Acta Hortic. 2008, 792, 135-139. [CrossRef]

38. Hoppula, K.I.; Salo, T.J. Tensiometer-based irrigation scheduling in perennial strawberry cultivation. Irrig. Sci. 2007, 25, 401-409. [CrossRef] 
39. Ozeki, M.; Tamada, T. The potentials of forcing culture of southern highbush blueberry in Japan. Acta Hortic. 2006, 715, 241-246. [CrossRef]

40. Ciordia, M.; García, J.C.; Díaz, M.B. Off-season production of southern highbush blueberries in the north of Spain. Acta Hortic. 2006, 715, 317-322. [CrossRef]

41. Ogden, A.B.; van Iersel, M.W. Southern highbush Blueberry production in High Tunnels: Temperatures, development, yield, and fruit quality during the establishment years. HortScience 2009, 44, 1850-1856. [CrossRef]

42. Kader, A.A. Quality and its maintenance in relation to the postharvest physiology of strawberry. In The Strawberry into the 21st Century; Dale, A., Luby, J., Eds.; Timber Press: Portland, OR, USA, 1991; pp. 145-152.

43. Kadir, S.; Carey, E.; Ennahli, S. Influence of high tunnel and field conditions on strawberry growth and development. HortScience 2006, 41, 329-335. [CrossRef]

44. Retamales, J.B.; Montecino, J.M.; Lobos, G.A.; Rojas, L.A. Colored shading nets increase yields and profitability of highbush blueberries. Acta Hortic. 2008, 770, 193-197. [CrossRef]

45. Lobos, G.A.; Retamales, J.B.; Del Pozo, A.; Hancock, J.F.; Flore, J.A. Physiological response of Vaccinium corymbosum "Elliott" to shading nets in Michigan. Acta Hortic. 2009, 810, 465-470. [CrossRef]

46. Hu, L.; Yang, C.; Zhang, L.; Feng, J.; Xi, W. Effect of light-emitting diodes and ultraviolet irradiation on the soluble sugar, organic acid, and carotenoid content of postharvest sweet oranges (Citrus sinensis (L.) osbeck). Molecules 2019, 24, 3440. [CrossRef] [PubMed]

47. Correia, S.; Gonçalves, B.; Aires, A.; Silva, A.; Ferreira, L.; Carvalho, R.; Fernandes, H.; Freitas, C.; Carnide, V.; Silva, A.P. Effect of Harvest Year and Altitude on Nutritional and Biometric Characteristics of Blueberry Cultivars. J. Chem. 2016, 2016, 1-12. [CrossRef]

48. Lee, S.K.; Kader, A.A. Preharvest and postharvest factors influencing vitamin C content of horticultural crops. Postharvest Biol. Technol. 2000, 20, 207-220. [CrossRef]

49. Scalzo, J.; Stevenson, D.; Hedderley, D. Blueberry estimated harvest from seven new cultivars: Fruit and anthocyanins. Food Chem. 2013, 139, 44-50. [CrossRef]

50. Gilbert, J.L.; Olmstead, J.W.; Colquhoun, T.A.; Levin, L.A.; Clark, D.G.; Moskowitz, H.R. Consumer-assisted selection of blueberry fruit quality traits. HortScience 2014, 49, 864-873. [CrossRef]

Publisher's Note: MDPI stays neutral with regard to jurisdictional claims in published maps and institutional affiliations.

(C) 2020 by the authors. Licensee MDPI, Basel, Switzerland. This article is an open access article distributed under the terms and conditions of the Creative Commons Attribution (CC BY) license (http://creativecommons.org/licenses/by/4.0/). 